\title{
Online lectures: An implementation of full e-learning action research
}

\author{
Roby Zulkarnain Noer ${ }^{1}$ *, Sucahyo Mas'an Al Wahid ${ }^{1}$, Rani Febriyanti ${ }^{2}$ \\ ${ }^{1}$ Department of Elementary School Teacher Education, Universitas Borneo Tarakan. \\ Jalan Amal Lama No.1, Kalimantan Utara 77123, Indonesia \\ 2 Departement of Primary Education, Pascasarjana, Universitas Negeri Yogyakarta. \\ Jalan Colombo No. 1, Yogyakarta 55281, Indonesia \\ * Corresponding Author. E-mail: robyznoer@gmail.com
}

Received: 14 October 2020; Revised: 24 October 2020; Accepted: 15 November 2020

\begin{abstract}
This study aimed to determine whether there is an increase in student learning outcomes after the implementation of online learning using the WhatsApp platform in the Children with Special Needs (CSN) course. This research method was a classroom action research conducted online using the WhatsApp platform. The classroom action research was carried out in 2 cycles with the stages including planning, implementing, observing, and reflecting. The subjects of this study were 21 PGSD UBT students in semester 6 of the 2019/2020 academic year. The data collection techniques used were observation, interviews, questionnaires, and test questions. While the research instruments used were observation sheets, interview sheets, online learning implementation questionnaires, and test questions. The data obtained were analyzed using qualitative and quantitative. The results of the study showed that the percentage of learning outcomes before and after being given learning treatment using the WhatsApp platform experienced a significant increase and had reached $85 \%$ completeness criteria. The online learning through the WhatsApp platform has some advantages, such as ease of use and development of courage in the discussion process. While the weakness is related to the unstable network and the lack of direct experience obtained through observations related to CSN material that requires direct practice in the field. This study was conducted as a contribution to the selection of learning media in a situation of Covid-19 pandemic, which requires learning to be conducted online or remotely.
\end{abstract}

Keywords: online learning, WhatsApp platform, learning outcomes, covid-19 pandemic.

How to Cite: Noer, R., Al Wahid, S., \& Febriyanti, R. (2021). Online lectures: An implementation of full e-learning action research. Jurnal Prima Edukasia, 9(1), 65-74. doi:https://doi.org/10.21831/jpe.v9i1.35030

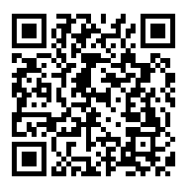

\section{Introduction}

The Covid-19 pandemic changes the entire learning process in the classroom. The government has started to take various actions to prevent transmission of the coronavirus by implementing social distancing and physical distancing. This decision impacted on the education system in Indonesia, whether elementary, secondary, and higher education, in which through a circular letter from the Ministry of Education and Culture, the changes are made in the implementation of the learning process. The effort made is to change the whole learning process in a full online mode (Gunawan et al., 2020; Naciri et al., 2020).

The online learning system in Indonesia is not new things that, based on data from SPADA Indonesia (2019), there are at least 54 universities implementing online modes. However, the use of online modes is always accompanied by face-to-face modes (blended learning). Changes in face-to-face learning or blended learning into a fully online system will certainly have an impact on the achievement of learning objectives (Setiawan et al., 2019). Orlando \& Attard (2016) stated that the use of the online mode is not necessarily suitable for all types of learning materials, so that online learning will have an impact on the achievement of learning objectives.

Online learning can be problematic one way or another, in which it can be useful for educators and students, and vice versa. Algahtani (2011) stated that full online learning can be synchronous or asynchronous if it is viewed based on the time of interaction between educators and students. They stated that the synchronous characteristic allows educators and students to interact directly at the same 
Jurnal Prima Edukasia, 9 (1), 2021 - 66

Roby Zulkarnain Noer, Sucahyo Mas'an Al Wahid, Rani Febriyanti

time through video conferencing or chat rooms. Meanwhile, the asynchronous characteristic occurs when educators and students learn at different times, for example, the educators use recorded videos.

The feedback received between synchronous online is direct, while asynchronous online is indirect. Dumford and Miller (2018) stated that the feedback that occurs in face-to-face classes must also be adapted in online learning. However, learning from the synchronous system is detrimental to areas with limited facilities because sometimes it is due to the poor internet connection or the inadequate infrastructure. On the other hand, learning from an asynchronous system tends to be beneficial because it can be accessed at a time that suits the needs of students, but it will be difficult for educators to provide feedback at that time because of the time difference.

Online learning in general is not perfect learning. Several studies even revealed that online learning eliminates "vital personal interactions" not only between educators and students, but also between each student (Dumford \& Miller, 2018). Abaidoo and Arkorful (2014) added that the most serious impact of online learning is that students experience contemplation, isolation, and a lack of interaction or relationships. This happens due to very limited clarifications, offers of explanation, and interpretation from the lecturers.

In the world of higher education, the online lecture system is a familiar matter for lecturers in universities. However, according to researchers, online learning or e-learning that utilizes the internet in special lectures at universities and does not require the presence of lecturers to have face-to-face integration is largely not carried out smoothly at the University of Borneo Tarakan (UBT). This definitely becomes a dilemma because the university is "forced" to carry out online learning during the Covid-19 pandemic.

The online learning at UBT which is located in the border area is a challenge so that eventually an Academic Notification Letter was issued by the Vice Chancellor for Academic Affairs number 594/UN51/TU/2020 stating that the online academic activity can use various e-learning applications as long as they do not burden students and still pay attention to learning outcomes. Based on the notification, the educators and students carry out online learning using "less adequate" platforms to facilitate the whole interaction. The most chosen platform by lecturers at UBT is WhatsApp which is a chat application. WhatsApp is an application that can be downloaded for free and requires a smartphone so that students can be actively involved in the learning process (Awada \& Wang, 2016). The Whatsapp application can be a flexible alternative media to use in online learning (Hamid et al., 2020).

However, the WhatsApp application is generally indeed less able to support learning compared to video conferencing applications, such as Zoom, especially related to lectures that require direct feedback, practicum, or field lectures. One of the courses that is not intensely optimal in online learning using Whatsapp is the Children with Special Needs (CSN) course. Based on the results of observations, the students still need consultation and guidance outside the scheduled class hours. Besides, the broad and casuistic scope of the material along with practice requires the students to always communicate with lecturers. This problem is of certainly a weakness of online learning using WhatsApp. Based on the above background, the objective and urgency of this study is to take online mode-based actions using the WhatsApp application, so that it will obtain formulations that are in accordance with the Children with Special Needs course.

\section{Method}

The method used was classroom action research. Classroom action research refers to Kemmis, McTaggart, \& Nixon (2014). The research is planned to be carried out in 2 cycles, if there are unsatisfactory results from student learning outcomes it will be continued to the next cycle until the goal is achieved (completeness above 85\%). Each cycle is carried out according to the changes to be achieved. Each cycle consists of the following steps: (1) action planning; (2) implementation of actions; (3) observation of learning actions and their impacts; and (4) reflection on learning actions that have been carried out, after data analysis is carried out then proceed with follow-up implementation.

The subjects of this study were Bachelor's Degree of Primary School Teacher Education (PGSD) students at the University of Borneo Tarakan (UBT) in semester 6 of the 2019/2020 academic year who attended the Children with Special Needs (CSN) course with a total of 21 students. The data collection techniques used were observations, interviews, questionnaires, and test questions. The instruments were used in the study to obtain the entire data from the perspective of students and observers. The instruments 
Jurnal Prima Edukasia, 9 (1), 2021 - 67

Roby Zulkarnain Noer, Sucahyo Mas'an Al Wahid, Rani Febriyanti

used included: (1) the semi-structured interview, which aims to obtain students' perceptions; (2) the short descriptive survey, which collects descriptive data about students' backgrounds; (3) feedback through the platform, which provides a qualitative description of student involvement in online learning; (4) observation sheets, which filled in by observers who will later join the WhatsApp group online lectures; and (5) test questions, which are carried out for the cognitive skills of students at the end of each cycle.

Data analysis techniques used are qualitative and quantitative included: (1) Classifying data by grouping, selecting, focusing, and simplifying data based on their type from the beginning of data collection to compiling the report; (2) Presentation of the data that have been selected and will be presented in the form of simple information. The information is a description of the learning process and the results are obtained from a combination of the observation, questionnaire, test and interview data; (3) Conclusion. The results of observations, questionnaires, and interviews will be analyzed descriptively qualitatively. Then the test results will be analyzed quantitatively by calculating the average pretest and posttest in cycles I and II.

Based on the data presentation, the conclusions were obtained in the form of a short sentence that has a broad meaning. The results of the conclusions were used to test the truth and match the meaning of the data obtained in the field. Student achievement assessments were obtained from cognitive test scores at the end of each cycle. To find out the improvement in student learning outcomes, it can be seen from the completeness of student learning outcomes in each cycle consisting of individual completeness and classical completeness. The students (individually) are considered completed in the learning process if the final grade reaches $\geq 70$, while the completeness is declared if the classical completeness score reaches $85 \%$.

\section{Results and Discussions}

The classroom action research carried out used online learning with the assistance of the WhatsApp platform. The subjects of this study were 21 students in semester 6 of the Primary School Teacher Education (PGSD) Study Program at the University of Borneo Tarakan (UBT). The classroom action research was carried out using 2 cycles in which each cycle consisted of 4 steps, including planning the action, implementing the action, observing the action, and reflecting on the action.

First, the study began with the planning stage. On cycle I, the planning stage was the stage of creating a learning plan that would be carried out by compiling a Semester Lesson Plan (RPS) and Lecture Program Unit (SAP) for online learning. Moreover, this stage also compiled instruments that would be used in the study, including tests used to measure student learning outcomes, online learning observation sheets, student interview sheets, and student questionnaires to find out students' conditions and perceptions related to online learning using the WhatsApp platform. The test questions were designed to find out whether online learning using the WhatsApp platform could improve student learning outcomes, especially in the Children with Special Needs (CSN) course.

It is also necessary to prepare a WhatsApp chat group as a communication medium to be used in the learning process. The WhatsApp group created is a forum used in the learning process to interact with each other, exchange information, and discuss the material being taught (Baishya \& Maheshwari, 2020). In particular, WhatsApp is currently the most significant and newest platform used around the world because it can change the learning process from formal to more social and open (Mpungose, 2020; Salmon, 2013).

After cycle I is over, the research is continued in cycle II by making a learning plan based on reflection in cycle I including the media used during the presentation is still not varied, the discussion process is still not optimal, and the lecture schedule changes frequently. Based on this reflection, the learning plan in cycle I was improved by adding an e-workshop by inviting several parties who were more experts related to Children with Special Needs.

The second was the action. On cycle I, before carrying out the action in the learning process, the students were provided with a pre-test to determine their initial abilities. The action implementation stage was the implementation of the plans that had been made in the RPS and SAP. The lecturers opened online learning by greetings and conveying learning objectives. The online learning process was carried out through the WhatsApp group application using chat, voice notes, documents, images, and videos. Before the learning process was carried out, the lecturer first divided the students into some groups along 
Jurnal Prima Edukasia, 9 (1), 2021 - 68

Roby Zulkarnain Noer, Sucahyo Mas'an Al Wahid, Rani Febriyanti

with the materials that would be discussed by each group at the previous meeting. Thus, each group could prepare the material to be presented. Then, at the second meeting, the learning process with group discussions could be carried out.

In cycle II, the actions taken are almost the same as in cycle I, namely with group discussions using the Whatsapp group. But at the end of the meeting, an e-workshop was held with several experts discussing "Learning Media for Children with Special Needs" with the help of the Zoom application. In this e-workshop, students get more real and valid information regarding children with special needs and get the opportunity to ask questions related to things that are not yet understood. The e-workshop flyer can be seen in Figure 1.

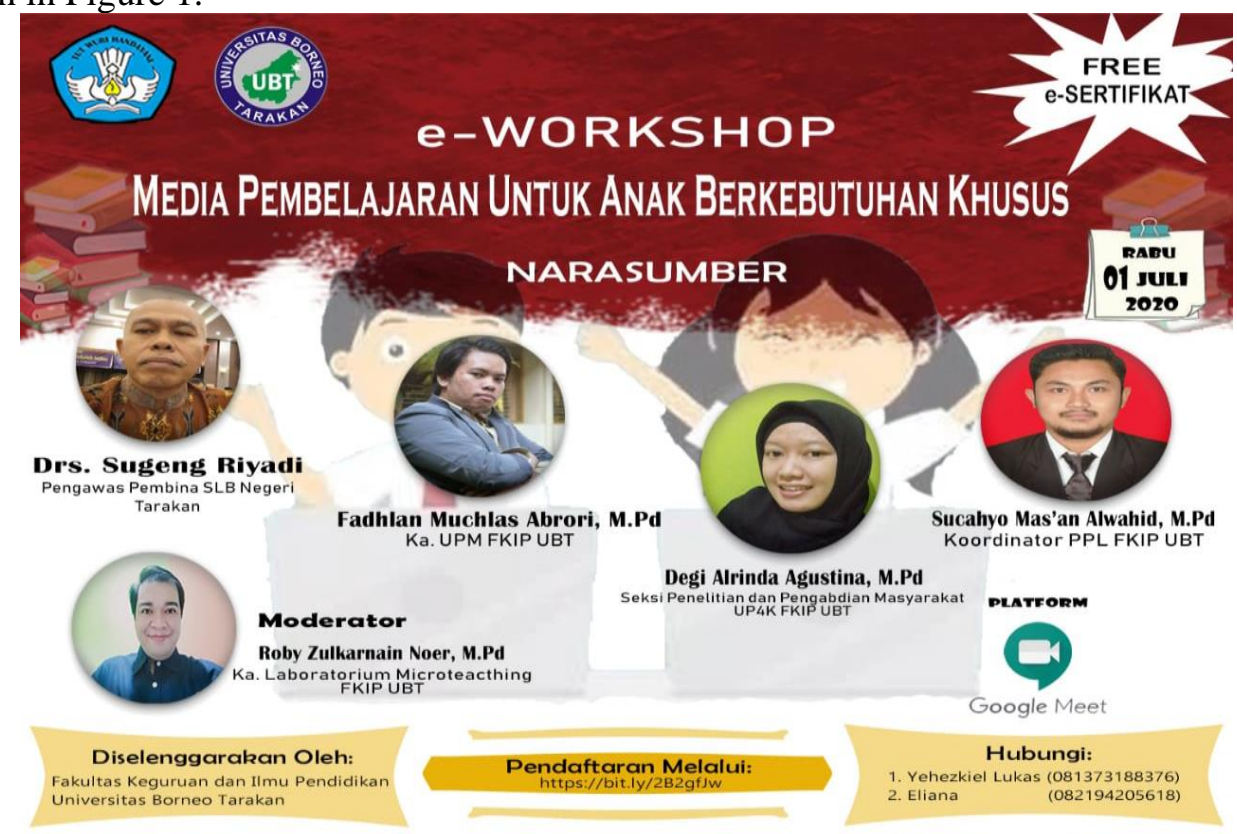

Figure 1. E-workshop on learning media for children with special needs

The third was the observation. During the process of action implementation, the observation stage was also carried out during the learning process. The observations were made by observers who were members of the WhatsApp chat group class. In the discussion process in cycle I, the groups of students who made presentations sent the results of their discussion through documents of Microsoft Word, PowerPoint, images, and videos related to the material being discussed. Then, the student group gave an explanation using the voice note feature on the WhatsApp application and chat. Once the material had been presented, a question and answer session was opened for students to the group of presenters. This question and answer process was conducted in 2 sessions with some questions per session. Based on the results of observations made by observers who took part in the learning process in the WhatsApp chat group, it was seen that only a few students seemed enthusiastic about online learning. This can be seen from the small number of students who asked questions.

The learning process in cycle II has the same process as cycle 1, the only difference is the eworkshop which is held at the end of the meeting. At the e-workshop, students were enthusiastic about participating in a series of activities. This can also be seen from the enthusiasm of students in asking questions to the speakers.

Based on interviews with some students, it obtained that in cycle I, the students were less active in the discussion and question and answer process because they did not understand the material presented. This was due to Internet network problems resulting in delays in the material being delivered, some students preferred to listen to the learning process, felt ashamed, and did not feel confident. However, in cycle II, it was seen that the students had started to actively participate in the learning process. Based on interviews with the students, it was found that they were getting used to online learning using the WhatsApp platform. Thus, the students were slowly able to take part in online learning properly and effectively. However, not all students experienced this. Several students also felt that the online learning had been carried out well and they easily understood the material presented by the presenters through the WhatsApp platform. Even though there were still inputs and suggestions for the 
Jurnal Prima Edukasia, 9 (1), 2021 - 69

Roby Zulkarnain Noer, Sucahyo Mas'an Al Wahid, Rani Febriyanti

learning process that had been carried out, they were still enthusiastic about participating in online learning.

Once the discussion and question and answer process ended, the lecturer gave comments and additional material on the results of the discussion that had been carried out. Besides, the lecturer also cleared up any misunderstandings that occurred during the discussion regarding the material being discussed. The lecturer as facilitators also actively participated as students who provided questions and answers but did not provide explicit answers to help students revealed the answers (Andújar-Vaca \& Cruz-Martínez, 2017). The learning process in cycles I and II occurred in 4 meetings for each cycle. After the fourth meeting, the students were given a post-test to find out whether there was an improvement in learning outcomes after implementing online learning using the WhatsApp platform.

The fourth was carrying out reflection. Once the online learning using the WhatsApp platform had been completed, the students were provided with a questionnaire via Google Form to find out their perceptions of online learning using the WhatsApp platform. Based on the results of Google Form in cycle I, the results of reflection on online learning using the WhatsApp platform were more interactive and communicative between the lecturer and students as the learning process took place, lecture schedule was fixed and did not change, and other applications such as Zoom or Google Meet could be used for variations in the learning process. The results of this reflection were used as the basis for the implementation of online learning through the WhatsApp platform in the cycle II.

The students also mentioned some advantages of using the WhatsApp platform in online learning including more flexible learning time and relaxed, gaining new experiences, the material presented could be easily documented, and more courageous to ask questions and express opinions in discussion sessions. This was supported by results of the study by Chng (2020) which stated that learning through WhatsApp can trigger student involvement, even allowing shy and less confident students to be more productive and more vocal on WhatsApp compared to the learning process in the classroom because WhatsApp provides democratic expression through information seeking, critical questions, and information sharing.

Besides sharing the advantages of using the WhatsApp platform in online learning, the students also conveyed the weaknesses of online learning using the WhatsApp platform including an unstable internet network, sometimes lack concentration in the learning process, excessive task loads, lecture schedules that often change not according to the set schedule, less optimal in understanding the material presented by the group at the time of presentation, and difficulty in coordinating with group members to complete group assignments given by the lecturer. Moreover, related to CSN learning, the students also said that they could not make direct observations related to character and way to deal with CSN because of the limited situation and the learning process that was carried out online. Thus, the students did not obtain direct experience in the application of the CSN material being taught.

Then the reflection in cycle II is also almost the same in cycle I, that is, some students still find it difficult to concentrate, the network is sometimes unstable due to the conditions of their living in the interior (due to pandemic conditions so that many students return to their hometowns like Malinau, Nunukan, Tanjung, and Berau), and group cooperation that is still not running well. However, many students admitted that they were enthusiastic and happy when an e-workshop was held where students could be involved in the process of implementing the e-workshop. They claim to get a lot of information related to children with special needs and can understand material that has not been understood before.

Besides providing the Google Form, the students were also given another test to find out whether online learning using the WhatsApp platform could improve student learning outcomes. To determine the results, the pre-test results would be compared with the post-test results conducted at the end of each cycle. The results obtained were then analyzed which can be seen in Table 1.

Table 1. Learning Outcomes Test Results

\begin{tabular}{clccc}
\hline \multirow{2}{*}{ Aspect } & \multicolumn{2}{c}{ Description } & \multirow{2}{*}{ Pre-test } & \multicolumn{2}{c}{ Cycle } \\
\cline { 4 - 5 } & Total & 1250 & I (Post-test) & II (Post-test) \\
\hline Learning Outcomes & Average & 59.52 & 73.89 & 1915 \\
& Completed & 47.6 & 57.1 & 91.19 \\
& Not Completed & 52.4 & 42.9 & 95.2 \\
& & & 4.8 \\
\hline
\end{tabular}


Jurnal Prima Edukasia, 9 (1), 2021 - 70

Roby Zulkarnain Noer, Sucahyo Mas'an Al Wahid, Rani Febriyanti

Based on Table 1, the total pre-test score was 1250 and the pre-test mean score was 59.52. Then, the total score of the post-test cycle I had increased, which was 1250 with an average of 73.89 . While the total score of the post-test cycle II also increased, which was 1915 with an average of 91.91. In accordance with the provisions, the students are considered completed if the final score reaches an average of $\geq 70$ and reaches $85 \%$ completeness. Based on Table 1, in cycle I, it can be seen that the average results reached 72.89 , which means that the average learning outcomes in cycle I had been completed. However, based on the completeness score, in cycle I, there was only $57.1 \%$ of students who had completed it, while $42.9 \%$ of students had not obtained the learning outcomes. Thereby, cycle I still did not meet the minimum completeness criteria.

Furthermore, it was followed by cycle II with the same procedure as cycle I. The average result in cycle II was 91.19 and met the minimum completeness requirements, which was $\geq 70$. For the completeness score in cycle II, $92.5 \%$ of students obtained completeness while $4.8 \%$ of students did not complete the learning outcomes. Thus, it can be concluded that the learning process in cycle II reached completeness, which means that online learning using the WhatsApp platform could improve student learning outcomes in the Children with Special Needs (CSN) course. For more details, it can be seen in Figure 2.

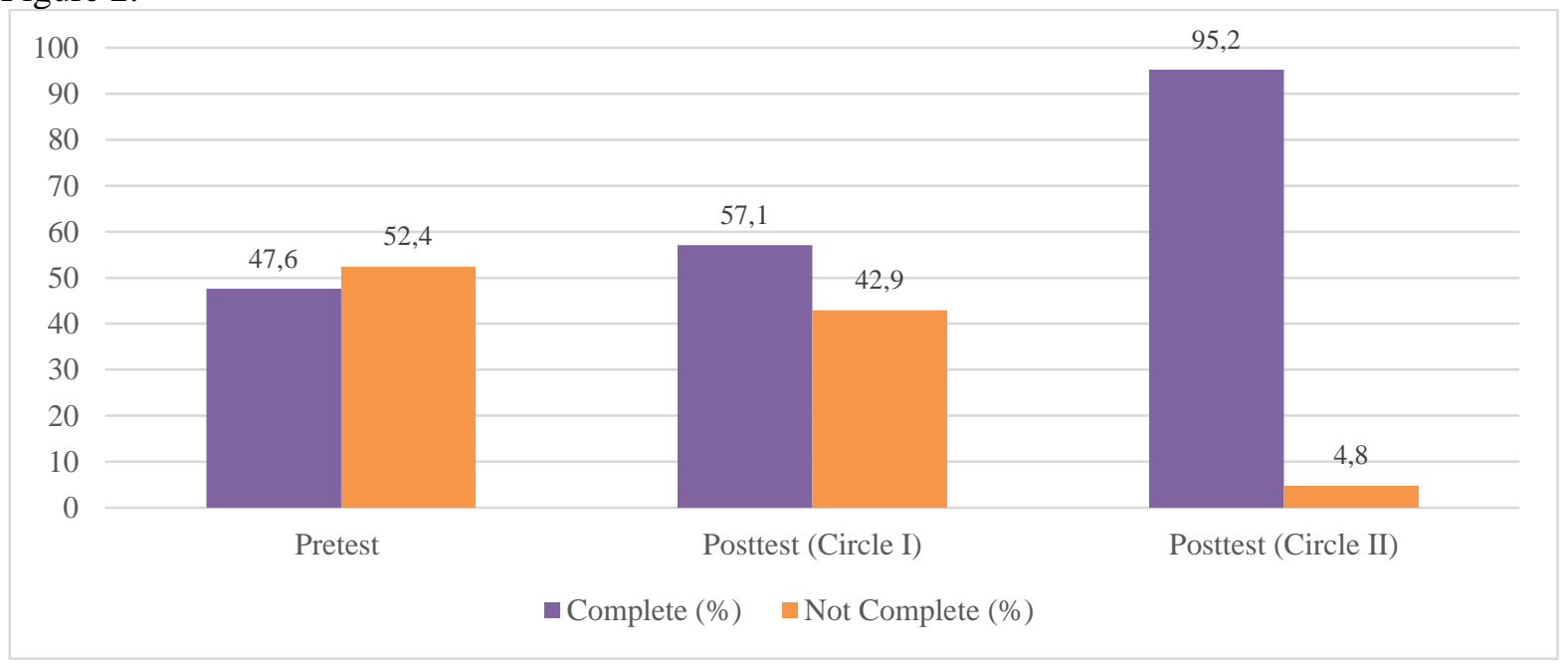

Figure 2. Graph of the Average Improvement of Student Learning Outcomes

Based on the graph of the average improvement of student learning outcomes, it can be seen that the students' completeness score from pre-test to post-test in cycle I had an improvement in the percentage of completeness when given learning treatment using the WhatsApp platform. Then, when given treatment again in cycle II, the percentage of student learning outcomes had increased again by $95.2 \%$ in which this percentage was greater than the percentage requirement, which was $85 \%$. Therefore, online learning using the WhatsApp platform could improve student learning outcomes in the Children with Special Needs (CSN) course.

A study conducted by Urien et al. (2019) showed that the scores obtained by students using WhatsApp were classified as high. It then helped students to develop technology skills, proficiency, finding answers to their questions, developing a sense of collaboration, and improvement of learning outcomes (Cetinkaya, 2017; Naciri et al., 2020; Rahaded et al., 2020; Robles et al., 2019). This is relevant to the results of this study that the WhatsApp application could improve student learning outcomes. Simple WhatsApp operation, fast process, and lower costs make the WhatsApp application broadly used in online learning (Baishya \& Maheshwari, 2020; Bouhnik \& Deshen, 2014; Tang \& Hew, 2017). However, the availability of the internet network was still inadequate for some UBT students, which had resulted in online learning sometimes being less effective. This is in line with a study conducted by Chng (2020) that several students might not be active in online learning due to the unavailability of a proper internet connection. Thereby, they could not take part in learning directly and could not reply to conversations during online learning using WhatsApp.

However, not all students perceived this way. Several students gave positive responses regarding the use of the WhatsApp application in online learning, which was easy to use to communicate and discuss relevant issues (Asterhan \& Bouton, 2017; Bar-Tal \& Asterhan, 2017; Urien et al., 2019) in 
Jurnal Prima Edukasia, 9 (1), 2021 - 71

Roby Zulkarnain Noer, Sucahyo Mas'an Al Wahid, Rani Febriyanti

which they could learn intimately and authentically to make learning fun (Bouhnik \& Deshen, 2014). This is also in line with the opinion of Awada and Wang (2016) that through the WhatsApp application, students could easily exchange information, answered questions quickly, built knowledge and improved class participation through message exchange on WhatsApp.

The online learning method used in this study was group discussion using the WhatsApp application. Thus, there was a need for cooperation between group members to achieve learning goals. Rambe and Bere (2013) argued that such cooperation could bridge the gap between knowledge and physical distance. The results of their study suggested that the WhatsApp application was a shared platform that could increase accessibility, drive teamwork, and intensify motivation to be actively involved in academic tasks. To facilitate online learning activities, the ability of a lecturer or teacher is needed to design learning material in an attractive multimedia form (Primamukti \& Farozin, 2018).

A similar study was also conducted by Amry (2014) who stated that the Whatsapp application could create a learning community that facilitated the spread of knowledge in a fast way. However, there was a need for a facilitator's role, in this case educators, to direct the learning members in the Whatsapp group, so that the presence of lecturers was very crucial in the WhatsApp group (Chng, 2020). Therefore, in this study, lecturers as facilitators assisted students in conducting group discussions and provided confirmation if there were misunderstandings that occurred during the discussion. Barhoumi (2015) stated that learning using Whatsapp improved communication between students to encourage them to be more productive. Integration of video, audio, images and podcasts in WhatsApp would be very helpful in the learning process (Rahaded et al., 2020). Particularly, as the current Covid-19 pandemic requires learning to be carried out online, the WhatsApp application can be used as an application that can be utilized in the online learning process.

The features of WhatsApp used in this study during online learning using WhatsApp included group chats, voice and video calls, sharing images, videos, and documents. By using these features, discussion-based learning could be carried out well even though there were still deficiencies in the implementation process, such as an unstable network. WhatsApp is also very popular and widely used today because of its ability to create group chats, voice messages, emoticons, phone calls and even share locations (Udenze \& Oshionebo, 2020).

There are 8 WhatsApp features that can be used according to Koomson (2018) in the learning process, including (1) simple and reliable text, (2) group chats to connect with other people, (3) web and desktop version which are useful for keeping conversations that taking place anytime and anywhere, (4) voice calls and videos that can be carried out when voice and text are considered insufficient, (5) endto-end encryption that provides security by default, (6) images and videos that provide users with the opportunity to share important moments, (8) voice messages using the voice message system to deliver material, (9) documents, which is to attach and share documents, such as PDFs, spreadsheets, slideshows, and word documents. Through those features available on WhatsApp, it is possible to have a reciprocal relationship between lecturers, presenters, and students (Naciri et al., 2020).

From an educational perspective, mobile instant messaging (MIM), including the use of the WhatsApp application, can be used to improve class participation and the learning process. By using WhatsApp, the time used in the learning process can be carried out spontaneously and can be carried out in many places (Ryu \& Parsons, 2012). The WhatsApp application can also be used as a support and communication tool in the transition from higher education institutions to professional life as a means of strengthening knowledge (Pimmer et al., 2019; Rosenberg \& Asterhan, 2018). Therefore, the WhatsApp application has various advantages related to the interaction between students, ease of sharing learning material, ease of accessing learning material, and high interaction with facilitators (Gon \& Rawekar, 2017).

This is also relevant to the results of this study, in which the WhatsApp application could be the right media to use in the learning process because of the various features that could make it easier to communicate and discuss the material being taught and could improve student learning outcomes. Particularly in the current Covid-19 pandemic condition which requires learning to be carried out online, the use of the WhatsApp application can be one of the right choices as a forum for carrying out the distance learning process. 
Jurnal Prima Edukasia, 9 (1), 2021 - 72

Roby Zulkarnain Noer, Sucahyo Mas'an Al Wahid, Rani Febriyanti

\section{Conclusions}

Based on the research data, it can be concluded that online learning using the WhatsApp platform could improve student learning outcomes in the Children with Special Needs (CSN) course. The percentage of learning outcomes before being given action was $47.6 \%$ of students who obtained completeness. The percentage of learning outcomes improved in cycle I after using the WhatsApp learning platform by $57.1 \%$ of students who obtained completeness. Further, it was given the treatment again in cycle II and obtained an improvement in the percentage by $95.2 \%$ of students who obtained completeness. Thus, online learning using the WhatsApp platform could be used in the learning process as a forum for communication and discussion between educators and students because the WhatsApp platform had various features that could be used in the learning process.

The learning process using the WhatsApp application can be carried out by taking turns in group discussions using various media as a presentation of material such as images, videos, sounds, power point, PDF, words, and others. The use of the Whatsapp application in online learning can be combined with other applications such as zoom or google meet as variations in online learning. So it takes the ability of teachers or lecturers and students to design learning materials attractively so that learning objectives can be achieved.

\section{References}

Abaidoo, N., \& Arkorful, V. (2014). Adoption and effective integration of ICT in teaching and learning in higher institutions in Ghana. International Journal of Education and Research, 2(12), 12. http://www.ijern.com/journal/2014/December-2014/35.pdf

Algahtani, A. F. (2011). Evaluating the effectiveness of the e-learning experience in some universities in Saudi Arabia from male students perceptions. Durham University.

Amry, A. B. (2014). The impact of WhatApp mobile social learning on the achievement and attitudes of female students compared with face to face learning in the classroom. European Scientific Journal, 10(22), 116-136. https://doi.org/10.19044/esj.2014.v10n22p\%25p

Andújar-Vaca, A., \& Cruz-Martínez, M.-S. (2017). Mobile instant messaging: Whatsapp and its potential to develop oral skills. Media Education Reserch Journal, 50(25), 43-52. https://www.scipedia.com/public/Andujar-Vaca_Cruz-Martinez_2017a

Asterhan, C. S. C., \& Bouton, E. (2017). Teenage peer-to-peer knowledge sharing through social network sites in secondary schools. Computers \& Education, 110, 16-34. https://doi.org/10.1016/j.compedu.2017.03.007

Awada, G., \& Wang, S. (2016). Effect of WhatsApp on critique writing proficiency and perceptions toward learning. Cogent Education, 3(1), 1264173. https://doi.org/10.1080/2331186X.2016.1264173

Baishya, D., \& Maheshwari, S. (2020). Whatsapp groups in academic context: Exploring the academic uses of whatsapp groups among the students. Contemporary Educational Technology, 11(1), 31-46. https://doi.org/10.30935/cet.641765

Bar-Tal, \& Asterhan, C. S. C. (2017). Going behind the scenes at teacher colleges: Online student knowledge sharing through social network technologies. Interdisciplinary Journal of E-Skills and Lifelong Learning, 13, 167-184. https://doi.org/https://doi.org/10.28945/3863

Barhoumi, C. (2015). The effectiveness of WhatsApp mobile learning activities guided by activty theory on students' knowldege management. Contemporary Educational Technology, 6(3), 221-238. https://doi.org/10.30935/cedtech/6151

Bouhnik, D., \& Deshen, M. (2014). WhatsApp goes to school: Mobile instant messaging between teachers and students. Journal of Information Technology Education: Research, 13, 217-231. https://doi.org/10.28945/2051

Cetinkaya, L. (2017). The impact of whatsapp use on success in education process. International Review of Research in Open and Distance Learning, 18(7), 59-74. https://doi.org/10.19173/irrodl.v18i7.3279

Chng, L. K. (2020). Face-to-face tutorials, learning management system and whatsapp group: How 
Jurnal Prima Edukasia, 9 (1), 2021 - 73

Roby Zulkarnain Noer, Sucahyo Mas'an Al Wahid, Rani Febriyanti

digital immigrants interact and engage in e-learning? Malaysian Online Journal of Educational Technology, 8(1), 18-35. https://doi.org/10.17220/mojet.2020.01.002

Dumford, A. D., \& Miller, A. L. (2018). Online learning in higher education: exploring advantages and disadvantages for engagement. Journal of Computing in Higher Education, 30(3), 452-465. https://doi.org/10.1007/s12528-018-9179-z

Gon, S., \& Rawekar, A. (2017). Effectivity of e-learning through Whatsapp as a teaching learning tool. MVP Journal of Medical Sciences, 4(1), 19-25.

https://doi.org/10.18311/mvpjms/2017/v4i1/8454

Gunawan, G., Suranti, N. M. Y., \& Fathoroni, F. (2020). Variations of models and learning platforms for prospective teachers during the COVID-19 pandemic period. Indonesian Journal of Teacher Education, 1(2), 61-70. https://journal.publication-center.com/index.php/ijte/article/view/95

Hamid, R., Sentryo, I., \& Hasan, S. (2020). Online learning and its problems in the Covid-19 emergency period. Jurnal Prima Edukasia, 8(1), 86-95. https://doi.org/doi:https://doi.org/10.21831/jpe.v8i1.32165 Introduction

Kemmis, S., McTaggart, R., \& Nixon, R. (2014). The action research planner: Doing critical participatory action research. In The Action Research Planner: Doing Critical Participatory Action Research. https://doi.org/10.1007/978-981-4560-67-2

Koomson, W. K. (2018). Mobile learning: Application of WhatsApp messenger as a learning tool in a university distance learning program in Ghana. Proceedings of the 15th International Conference on Cognition and Exploratory Learning in the Digital Age, CELDA 2018, 45-52.

Mpungose, C. B. (2020). Is Moodle or WhatsApp the preferred e-learning platform at a South African university? First-year students' experiences. Education and Information Technologies, 25(2), 927-941. https://doi.org/10.1007/s10639-019-10005-5

Naciri, A., Baba, M. A., Achbani, A., \& Kharbach, A. (2020). Mobile learning in higher education: Unavoidable alternative during COVID-19. Aquademia, 4(1), ep20016. https://doi.org/10.29333/aquademia/8227

Orlando, J., \& Attard, C. (2016). Digital natives come of age: the reality of today's early career teachers using mobile devices to teach mathematics. Mathematics Education Research Journal, 28(1), 107-121. https://doi.org/10.1007/s13394-015-0159-6

Pimmer, C., Brühlmann, F., Odetola, T. D., Oluwasola, D. O., Dipeolu, O., \& Ajuwon, A. J. (2019). Facilitating professional mobile learning communities with instant messaging. Computers and Education, 128, 102-112. https://doi.org/10.1016/j.compedu.2018.09.005

Primamukti, A. D., \& Farozin, M. (2018). Utilization of interactive multimedia to improve learning interest and learning achievement of child. Jurnal Prima Edukasia, 6(2), 111-117. https://doi.org/10.21831/jpe.v6i2.19183

Rahaded, U., Puspitasari, E., \& Hidayati, D. (2020). The impact of Whatsapp toward uad undergraduate students' behavior in learning process. International Journal of Educational Management and Innovation, 1(1), 55. https://doi.org/10.12928/ijemi.v1i1.1515

Rambe, P., \& Bere, A. (2013). Using mobile instant messaging to leverage learner participation and transform pedagogy at a South African University of Technology. British Journal of Educational Technology, 44(4), 544-561. https://doi.org/10.1111/bjet.12057

Robles, H., Guerrero, J., Llinás, H., \& Montero, P. (2019). Online teacher-students interactions using Whatsapp in a law course. Journal of Information Technology Education: Research, 18, 231252. https://doi.org/10.28945/4321

Rosenberg, H., \& Asterhan, C. S. C. (2018). "Whatsapp, teacher?” - Student perspectives on teacherstudent whatsapp interactions in secondary schools. Journal of Information Technology Education: Research, 17, 205-226. https://doi.org/10.28945/4081

Ryu, H., \& Parsons, D. (2012). Risky business or sharing the load? - Social flow in collaborative mobile learning. Computers and Education, 58(2), 707-720.

https://doi.org/10.1016/j.compedu.2011.09.019

Salmon, G. (2013). E-tivities: Teh key to active online learning. Routledge. 
Jurnal Prima Edukasia, 9 (1), 2021 - 74

Roby Zulkarnain Noer, Sucahyo Mas'an Al Wahid, Rani Febriyanti

Setiawan, R., Mardapi, D., Pratama, A., \& Ramadan, S. (2019). Efektivitas blended learning dalam inovasi pendidikan era industri 4.0 pada mata kuliah teori tes klasik. Jurnal Inovasi Teknologi Pendidikan. https://doi.org/10.21831/jitp.v6i2.27259

Tang, Y., \& Hew, K. F. (2017). Is mobile instant messaging (MIM) useful in education? Examining its technological, pedagogical, and social affordances. Educational Research Review, 21(Mim), 85-104. https://doi.org/10.1016/j.edurev.2017.05.001

Udenze, S., \& Oshionebo, B. (2020). Investigating 'Whatsapp' for collaborative learning among undergraduates. Üsküdar Üniversitesi İletişim Fakültesi Akademik Dergisi Etkileşim, 5, 24-50.

Urien, B., Erro-Garcés, A., \& Osca, A. (2019). WhatsApp usefulness as a communication tool in an educational context. Education and Information Technologies, 24(4), 2585-2602. https://doi.org/10.1007/s10639-019-09876-5 